Meta

Journal des traducteurs

Translators' Journal

\title{
Measuring Translation Competence Acquisition
}

\section{Mariana Orozco et Amparo Hurtado Albir}

Volume 47, numéro 3, septembre 2002

URI : https://id.erudit.org/iderudit/008022ar

DOI : https://doi.org/10.7202/008022ar

Aller au sommaire du numéro

\section{Éditeur(s)}

Les Presses de l'Université de Montréal

ISSN

0026-0452 (imprimé)

1492-1421 (numérique)

Découvrir la revue

Citer cet article

Orozco, M. \& Hurtado Albir, A. (2002). Measuring Translation Competence Acquisition. Meta, 47(3), 375-402. https://doi.org/10.7202/008022ar

\section{Résumé de l'article}

Nous décrivons dans cet article l'élaboration d'une série d'instruments de mesure conçus pour évaluer le processus d'acquisition de la compétence en traduction écrite. Nous définissons tout d'abord la compétence en traduction et son processus d'acquisition, et décrivons ensuite trois instruments de mesure de l'acquisition de la compétence en traduction, qui ont été conçus, puis perfectionnés et validés au cours d'épreuves pilotes réalisées sur trois ans. Ces instruments mesurent (i) la conception générale de la traduction, (ii) la manière dont des étudiants de traduction font face aux problèmes de traduction, ainsi que (iii) les erreurs de traduction. Enfin, nous proposons les éléments d'un projet de recherche, à savoir : l'objet d'étude, les variables dépendantes et indépendantes, les hypothèses, le nombre et les caractéristiques des mesures et les échantillons à utiliser.
Ce document est protégé par la loi sur le droit d'auteur. L'utilisation des services d'Érudit (y compris la reproduction) est assujettie à sa politique d'utilisation que vous pouvez consulter en ligne.

https://apropos.erudit.org/fr/usagers/politique-dutilisation/ 


\title{
Measuring Translation Competence Acquisition
}

\author{
MARIANA OROZCO AND AMPARO HURTADO ALBIR \\ Universitat Autònoma de Barcelona, Barcelona, Spain
}

\begin{abstract}
RÉSUMÉ
Nous décrivons dans cet article l'élaboration d'une série d'instruments de mesure conçus pour évaluer le processus d'acquisition de la compétence en traduction écrite. Nous définissons tout d'abord la compétence en traduction et son processus d'acquisition, et décrivons ensuite trois instruments de mesure de l'acquisition de la compétence en traduction, qui ont été conçus, puis perfectionnés et validés au cours d'épreuves pilotes réalisées sur trois ans. Ces instruments mesurent (i) la conception générale de la traduction, (ii) la manière dont des étudiants de traduction font face aux problèmes de traduction, ainsi que (iii) les erreurs de traduction. Enfin, nous proposons les éléments d'un projet de recherche, à savoir: l'objet d'étude, les variables dépendantes et indépendantes, les hypothèses, le nombre et les caractéristiques des mesures et les échantillons à utiliser.
\end{abstract}

\begin{abstract}
The following article describes the development of instruments for measuring the process of acquiring translation competence in written translation. Translation competence and its process of acquisition are firstly described, and then the lack of empirical research in our field is tackled. Thirdly, three measuring instruments especially developed to measure translation competence acquisition are presented: (i) to measure notions about translation, (ii) to measure students' behaviour when faced with translation problems, and (iii) to measure errors. Pilot studies were carried out for three years to test, improve and validate the measuring instruments. Finally, a future research project, which shows a possible application of the measuring instruments, is presented, and the main elements of the research project are described: the construct, dependent and independent variables, hypotheses, moments of measurements and the samples to be used.
\end{abstract}

\section{MOTS-CLÉS/KEYWORDS}

competence acquisition, measuring instruments, translation notions, translation errors, translation problems

\section{TRANSLATION COMPETENCE AND ITS ACQUISITION: PROBLEMS OF DEFINITION}

Translation Studies have not yet yielded a generally accepted definition and model of translation competence in written translation. The problems with the definition of this concept start with its denomination. It has been called transfer competence (Nord, 1991: 161), translational competence (Toury, 1995: 250-51; Hansen, 1997: 205; Chesterman, 1997: 147), translator competence (Kiraly, 1995: 108), translation performance (Wilss 1989: 129), translation ability (Lowe, 1987: 57; Pym, 1993: 26; Stansfield, Scott y Kenyon 1992) and even translation skill (Lowe, 1987: 57).

Of all these proposals, we prefer translation competence because it already has a long research tradition in other fields, such as Applied Linguistics, ${ }^{1}$ and therefore we have no need to create a new word, since the combination of 'translation' and 
'competence'-understood as 'an expert knowledge in a specific area'-, conveys exactly the idea we have of this concept.

But the problems of definition with translation competence do not end with its denomination. In fact, there are several authors who mention translation competence but do not define it; for instance, Nord (1991: 150, 152, 155; 1996: 101), Riedemann (1996: 117), Lörscher (1991: 41; 1992a: 426), Toury (1991: 62, 1995: 25051), Krings (1986: 501,522 in Fraser 1996a: 72), Fraser (1996b: 87), Lowe (1986: 53.61), Hansen (1997: 205) and Kiraly (1995: 13-19). It is obvious that these authors have a definition of translation competence in mind, but they do not make it explicit. We have found only four explicit definitions of translation competence, which are the following: Bell (1991: 43) defines translation competence as "the knowledge and skills the translator must possess in order to carry out a translation"; Hurtado Albir defines it as "the ability of knowing how to translate" (1996: 48); Wilss says translation competence calls for "an interlingual supercompetence [...] based on a comprehensive knowledge of the respective SL and TL, including the text-pragmatic dimension, and consists of the ability to integrate the two monolingual competencies on a higher level" (1982: 58).

Finally, the fourth definition, and the one we adopt in this article, is that of PACTE research group $^{2}$ (see PACTE 2000), which defines translation competence as "the underlying system of knowledge and skills needed to be able to translate." This definition is completed with four affirmations, namely that (i) translation competence is actualised in different ways in different situations, (ii) it consists basically of operative knowledge, (iii) strategies play a basic role in translation competence and (iv) as in any kind of expert knowledge, most translation competence processes are automatic.

There are many proposed models of how translation competence works, but we will only refer to them, since they can be easily consulted. These include the componential proposals of Beeby (1996: 92), Bell (1991: 41-43), Hansen (1997: 205-207), Hatim and Mason (1997: 205-6), Hurtado Albir (1996a: 34, 1996b: 39, 1999a: 43), Hewson and Martin (1991: 52), Lowe (1987: 53-55), Neubert (2000) and Nord (1991: 161 and 1992: 47), which distinguish various TC sub-competencies (linguistic, extra-linguistic, transfer, etc.); translation skills related to use as proposed by Pym (1992); the distinction between declarative and operative knowledge in translation competence made by Presas (1996); the pragmatic-cooperative model of Risku (1998); the model integrating knowledge and skills of Kiraly (1995); and the inverse TC model suggested by Campbell (1998). Among the componential proposals, we would like to highlight that of PACTE, which seems to us the most complete, including six interrelated TC sub-competencies: communicative competence in two languages, extra-linguistic competence, transfer competence, instrumental competence, psycho-physiological competence and strategic competence. Transfer and strategic competence are essential; transfer, because it integrates all the others, and strategic, because it affects the others, making up for deficiencies and solving problems in all of them. ${ }^{3}$

If there are problems of definition concerning translation competence, the situation of translation competence acquisition is clearly worse, as we do not find a single explicit definition, although several authors propose models of how this learning process develops. Harris and Sherwood (1978) postulated a natural translation 
ability, a kind of innate ability possessed by any multilingual speaker as the basis of TC. Toury (1986) accepted this innate ability, which is coextensive with bilingualism and mainly linguistic, but said that the translator must also develop a second ability, that of transfer, in order to develop translation competence. Shreve (1997) suggested that TC was a specialisation of communicative competence that developed from natural translation to constructed translation. Chesterman (1997) proposed five stages, based on Dreyfus and Dreyfus (1986): novice, advanced beginner, competence, proficiency and expertise. PACTE also has developed a model of translation competence acquisition (see PACTE, 2000), which considers that it is a dynamic process of building new knowledge on the basis of the old, as it takes place through a process of developing and restructuring the six sub-competencies of the TC. According to this model, the process requires development from novice knowledge (pre-translation competence) to expert knowledge (translation competence), it is a dynamic, cyclical process with successive restructuring, it requires learning competence (and thus, learning strategies), and finally it produces a restructuring and integrated development of declarative and operative knowledge.

\section{THE LACK OF EMPIRICAL RESEARCH}

Empirical research in Translation Studies started appearing at the end of the 1980s and, after analysing a representative number of research studies carried out on written translation, we have come to the conclusion that most of them show major problems not only from the scientific point of view, since they lack some of the essential components for their results to be generalized, as we will show later, but also from the theoretical point of view, because none of them tackles translation competence or the translation process as a whole, but only some of its aspects. This creates a situation where it is difficult for the researcher who wants to start new research not to start again from zero, since the different research studies carried out cannot be replicated (due mostly to lack of data about subjects, materials used, etc.) or their conclusions brought together to form a model. To show the variety of objectives in the research carried out on written translation, we have classified the studies reviewed, according to their main objective:

FIGURE 1

Research on written translation (Orozco, 2000: 48-49)

1. Relevance of certain elements during the translation process

Dechert and Sandrock 1986 (translation unit); Séguinot 1989 (translation brief and editing); Jääskeläinen 1990 (conscious attention); Englund 1993 (comprehension process); Shreve, Schäefnner et al. 1993 (reading in the comprehension process); Tirkkonen-Condit 1993 (cohesion structures in the SL); Dancette and Ménard 1996 (comprehension process); Königs and Kauffmann 1996; Halskov 1998, 1999 (comprehension process); Jensen 1999 (time limit); Lorenzo 1999a (comprehension process).

2. Translation problems and strategies

Dollerup 1982, Krings 1986, 1987; Königs 1987; Tirkkonen-Condit 1989; Lörscher 1991, 1992, 1996; Mondhal and Jensen 1996; Kussmaul 1997 (creativity problems); González, Rodríguez and Scott-Tennent 2000; Hansen 1999. 
3. Translation competence elements

Kussmaul 1991 (creativity); Mondhal and Jensen 1992 (linguistic knowledge); TirkkonenCondit 1992 (linguistic and encyclopaedic knowledge); Fraser 1993 (cultural transfer); Laukkanen 1993 (routine); Schäeffner 1993 (translator knowledge); Dancette 1994, 1997 (extralinguistic and specialised knowledge); Dancette 1995 (linguisitic and extralinguisitic competence); Kussmaul 1995 (creativity); Alves 1996 (linguisitc and cultural competence); Tirkkonen-Condit and Laukkanen 1996 (affectivity); Atkins and Varantola 1997 (documentation); Livbjerg and Mees 1998, 1999 (documentation).

4. Translation competence of the professional translator

Jäaskeläinen 1987; Krings 1988; Gerloff 1988; Jääskeläinen 1989; Tirkkonen-Condit 1990; Jääskeläinen and Tirkonen-Condit 1991; Fraser 1994; Lorenzo 1998, 1999b (inverse translation).

5. Translation training

Séguinot 1991 (learning strategies); Kiraly 1995; Hansen 1997; Kiraly 1997 (assessment); Neunzig 1997a, 1997b, 1998 (the computer as virtual translation teacher); Roiss 1998; Waddington 1999 (assessment); Fox 2000 (translation diaries).

6. TAPs as a measuring instrument

Gerloff 1987; Jääskeläinen 1993.

The studies reviewed have received a good deal of criticism from researchers within our field. This criticism is focused on three aspects: the samples used, the design of the studies and the use of Think-Aloud Protocols (TAPs) as an instrument to elicit data.

As far as the samples are concerned, there have been mainly two problems. First of all, the sizes of the samples are often too small and do not allow relevant conclusions to be drawn or the results of any given study to be generalized. Secondly, the samples are often not representative of the target population the researchers want to study (because they are too heterogeneous or because they do not fulfil the requirement of the target population) and this causes the same effect: the results cannot be generalized, since a change in the characteristics of the subjects could easily modify the results and thus the conclusions of the study are weak. Examples of such problems with the samples, often recognised by the researchers themselves, are the research of Krings (1986) and König and Kauffmann (1996), where foreign language students translate literary texts into the foreign language (not the 'ideal' literary translators); Königs (1987), where the sample is composed by one professional translator and four foreign language students; Tirkkonen-Condit (1992 and 1993), where two of the three subjects who make up the sample translate into the foreign language and the third into his mother tongue; Krings (1987) and Laukkanen (1993), where the sample is made up of a single subject; Dancette and Ménard (1996), where the sample is made up of two professional translators and three students, etc.

The second cause of the criticism these studies have received is the experimental design, and we could sum up four specific points: (i) the lack of a clear or welldefined objective before starting the research, (ii) studies whose objectives are much too ambitious in view of the samples and the instruments used to elicit data, (iii) imprudent generalization of the results obtained and (iv) lack of objectivity in order to interpret the results of the study. Since there are already a number of authors who have observed these points, we will refer to them for further details and examples (see Gile 1991: 165; Toury 1991: 62-63; Fraser 1996a: 75-77; Hurtado Albir 1996: 12; Presas 1996: 29; Orozco 2000: 59-62). 
The third and last point which has attracted criticism is the instruments used to elicit data in the studies. Although these studies use different instruments, those most frequently used, in $75 \%$ of the cases, are the introspective and retrospective techniques known as Thinking-Aloud Protocols (TAPs), i.e. the verbalization of mental processes, which are recorded in protocols. Apart from the fact that TAPs have been widely criticised on the basis that they only reveal conscious processes that can be verbalized and that the retrospective TAPs do not reflect operations controlled by short-term memory (in this sense, see, for instance, Kiraly 1995: 39-51; Dancette and Ménard 1996: 142; Fraser 1996a: 67; Hurtado Albir 1996: 57; Presas 1996: 24; Dancette 1997: 85; Bell 1998: 189; Hansen 1998: 62-63; Jääskeläinen 1998: 265-269) they are a method taken from another discipline, psychology, and this shows one of the main problems researchers in our field face when designing new research: the lack of measuring instruments designed specifically for our field of studies. Thus, we only know of two instruments of this kind: the translation task (a text given to a subject which s/he must translate according to a brief), sometimes followed by the use of specific questionnaires, and the computer, namely two programs: Translog (created by Jakobsen, see Jakobsen 1998 and 1999) and Proxy (which has been adapted by PACTE in order to study translation competence).

Fortunately, more and more researchers are starting to use these programs, and there is an increasing trend towards the use of measuring instruments specially created for our field, but we still acknowledge the lack of instruments to observe, for instance, the process of acquisition of translation competence. We therefore consider that one of the main challenges facing empirical-experimental research in written translation is methodological, and in particular, the difficulty of developing appropriate measuring instruments.

With these ideas in mind, we decided to create measuring instruments specifically built to make a longitudinal study of the process of acquisition of written translation competence, a basic point in the theory of Translation Studies that nonetheless has only been studied through observation, experience and research in other disciplines, and never using large, representative samples.

\section{BUILDING THREE MEASURING INSTRUMENTS OF TRANSLATION COMPETENCE ACQUISITION}

\subsection{Operationalizing the construct: the dependent variables}

The first step in order to create measuring instruments is to define clearly the object that one wishes to measure or, in other words, what is the construct. In this case, the construct is translation competence acquisition, as we have already defined it, and the next step is to decide which elements, representative of the construct, are going to act as indicators, in order to make the construct observable and operational.

To make translation competence acquisition operational we have chosen to observe three indicators, which are also our dependent variables, that share three characteristics we consider basic. First, all three affect the whole process of translation, not just some of the stages (comprehension, deverbalization and reformulation). Second, they are observable and can therefore be measured, and this makes them suitable for the research we wish to carry out. Finally, all three give us an indirect 
view of translation strategies, a phenomenon that is difficult to observe directly and yet is essential to the translation competence model that is the theoretical basis of our research.

The three dependent variables chosen are (i) behaviour when faced with translation problems, (ii) behaviour related to translation errors and (iii) general notions about translation. Translation scholars have offered several different definitions of these variables, but we do not intend to contribute to this debate here. The definitions on which the instruments created are based are as follows.

According to Nord (1991: 151), a translation problem is "an objective problem which every translator (...) has to solve during a particular translation task." In our opinion, all translation problems share three characteristics that make them reliable indicators of progress in acquiring translation competence: a translation problem may appear at any stage of the translation process; it is observable, as will be explained in the section describing the development of the translation problem instrument; and, in solving translation problems, subjects certainly show their ability to use translation strategies, which is a relevant element of translation competence.

The origin of a translation error (Nord 1996: 96-100) is usually a translation problem that has not been solved or has not been appropriately solved. Again, this element can be observed, it can take place at any stage of the translation process and it is also an indicator of a subject's use of translation strategies and thus of the subject's translation competence. Translation errors therefore present the same three qualities as translation problems.

Finally, general knowledge of translation or notions of translation, determine the students' whole process of translation, since, depending on the students' ideas about translation, they will have a particular purpose for a particular translation task, and this will determine their solution of translation problems throughout the process of translation. Thus, students who find a problem in the source text can either ignore it or try to solve it. Should they decide to solve it, it is because they want the target readers to understand or receive the target text in a certain way, and this is only possible if they have a particular concept of translation in the back of their minds. If this concept did not exist, then there would not be an objective to achieve. In this case, errors (and/or unsolved problems) can be caused by this "lack of knowledge" of general translation concepts. Thus, translation notions also share the same three qualities mentioned above.

\subsection{Measuring Instruments}

Three measuring instruments were thus created: one to measure behaviour when faced with translation problems, the Translation Problems Instrument (TPI), a second to measure errors, the Translation Errors Instrument (TEI) and a third to measure knowledge about translation, the Translation Notions Instrument (TNI). Each of the three instruments is to be applied twice, once at the beginning of training (that is, when undergraduate translation students start their first year at University) and the second, eight months later, once the first year of translation training is completed. 


\subsubsection{Translation Notions Instrument}

The TNI can be seen in appendix 1. It is a test made up of 14 items of three classes: multiple choice, true/false and open items. It is a multidimensional questionnaire because there are several relevant factors within the "abstract" notion of what translation is. Most of these factors are reflected in the questionnaire: notions about translation, elements that intervene in translation, notions about translation problems, the translation unit, translation equivalence, translation function, translation competence and its sub-competencies, and finally, strategies to solve comprehension problems in the foreign language and reformulation in the mother tongue.

Given the variety of factors represented in the questionnaire, they have been grouped in two main sections: (a) notions about translation and (b) notions about translation competence, with six items in each section. However, items 5 and 6 in Appendix 1 are not included in either section because they ask for qualitative information and these questions are not graded. The total results of the TNI for each individual are not compared with the rest of the group, but are compared with the individual's results in future measurements. The average progression of the group is calculated by adding up the progress made by each individual between the two measurement times. This sum is then divided by the number of subjects. As each conceptual section has six questions, each section has the same number of possible points.

\subsubsection{Translation Problems Instrument}

There are two parts to the TPI. The first is the task of translating a text - with a translation brief (see Appendix 2) — where four translation problems have been previously identified. The four types of problems chosen are pragmatic, extra-linguistic, transfer and linguistic. We have chosen these types of problems because in order to solve them, the translator has to mobilise nearly all the translation competence subcompetencies. The specific problems chosen were as follows.

a) Linguistic problem: flying (line 21). This is a language comprehension problem because in this text the usage of flying is not the most usual one. Furthermore, there is a reformulation problem because bilingual dictionaries do not offer an adequate equivalent.

b) Extra-linguistic problem: Sunday and weekly papers (line 11). This is a cultural problem because the distinction does not exist in Spain; although the weekly papers have a Sunday edition, the concept is not quite the same. Therefore, following the brief, the translator has to make a cultural adaptation or find some other solution, for example, to generalize and refer to all the publications mentioned in the press as revistas $y$ periódicos, or publicaciones diarias o semanales, etc.

c) Transfer problem: It's ideal for beginners. Details free. No cost. No obligation. Send the coupon. (lines 22-23). The transfer problem here is a conflict between cohesion patterns in English and Spanish. The normal pattern in Spanish would be a single sentence, or two at the most, with the ideas linked by connectors and references. A possible solution is: "Este curso de primera clase, ideal para principiantes, le asegura un comienzo brillante $y$ le permite ganar dinero mientras aprende. Le ofrecemos (...) Conozca más detalles de manera gratuita y sin ningún compromiso enviando el siguiente cupón."

d) Pragmatic problem: Britain (line 10). The translation brief specifically states that the translation is an advertisement for a writing course in Spanish, offered by a company based in Madrid. Therefore, it makes no sense to give the reader information about 
what happens in Great Britain, and the information should be adapted to the new context, substituting Britain with España.

Once the subjects have translated the text, they are asked to answer the TPI questionnaire (Appendix 3). The evaluator uses the translation, along with some of the questions, to grade the subjects' behaviour when faced with translation problems. The numerical scale used for grading is as follows:

0 - Problem undetected.

1 - Problem detected but not solved.

2 - Problem solved.

The evaluator refers to the translated text, together with the TPI questionnaire, to see if the subject qualifies for a " 0 ," a " 1 " or a " 2 ." First of all, the subject's translation has to be checked to decide if each problem has been solved adequately or not. Then, in order to know if the problem has been detected or not, questions 10, 11 and 12 of the questionnaire are looked at. Question 10 combines a multiple-choice question with an open question to see which problems the subject has detected in the text (a maximum of 5 problems). Questions 11 and 12 supplement the information in item 10, by seeing if the subject has recognised the four problems chosen previously.

The TPI questionnaire includes a further 11 items that give qualitative information about the translation process followed by the subject (particularly, about the strategies used). The value of this information is that it can be compared with the same subject's replies in later measurements (with different texts), giving a vision of each subject's progress. However, if the investigator wishes, these items can be suppressed, as they do not affect the TPI's final results, which are only based on the text and the answers to questions 10,11 and 12 .

\subsubsection{Translation Errors Instrument}

The TEI is also divided into two parts. The first part coincides with the first part of the TPI, that is, the translation of a text. The second part is the correction of the translation to check how many errors there are of each type. The error types that were taken into consideration for the validity and reliability tests were wrong meaning (segments of the translation that had a different meaning from the ST) and no meaning (segments of the translation that were meaningless, i.e. would not be understood by the translation reader). The number of successful solutions was also taken into account. These are segments of the translation that are particularly good, either because they offer an original, creative solution to one of the problems - adequate to the function of the translation - or, because that part of the translation reads like an original text in Spanish.

Although we have chosen these three categories (wrong meaning, no meaning and successful solution), the investigator can choose to observe other categories in each measurement. For example, we could observe the number of wrong meanings a subject makes in each measurement, or we could observe lexical and syntactic calques, etc. ${ }^{4}$ 


\subsection{Pilot studies}

The idea of creating three instruments to measure translation competence acquisition emerged in June 1996, and since then the instruments have been tested, improved and finally validated by three years of pilot tests, before acquiring the format that has just been presented. Each of the instruments has undergone a series of different changes, and on occasion tests have been carried out with one or two of the instruments, depending on the characteristics of each instrument. Figure 2 shows a list of all the different pilot tests carried out to date.

FIGURE 2

Pilot tests carried out for each of the three measuring instruments (Orozco 2000: 144)

\begin{tabular}{|c|c|c|}
\hline Instrument, version, language & Date / Number of test & $\begin{array}{l}\text { Place where the test was carried } \\
\text { out and number of students } \\
\text { who participated }\end{array}$ \\
\hline $\begin{array}{l}\text { TPI, English first version } \\
\text { TEI, first version } \\
\text { TNI, English first version }\end{array}$ & October 1996 / 1 & UAB, 25 students \\
\hline $\begin{array}{l}\text { TPI, English second version } \\
\text { TNI, English second version }\end{array}$ & October 1997 / 2 & UAB, 27 students \\
\hline TPI, English third version & February 1998 / 3 & UAB, 33 students \\
\hline $\begin{array}{l}\text { TPI, English fourth version } \\
\text { TPI, French fourth version } \\
\text { TPI, German fourth version }\end{array}$ & April 1998 / 4 & $\begin{array}{l}\text { UAB, } 28 \text { English students } \\
\text { UAB, } 14 \text { French students } \\
\text { UAB, } 13 \text { German students }\end{array}$ \\
\hline TPI, English fifth version & May 1998 / 5 & UAB, 19 students \\
\hline $\begin{array}{l}\text { First validity and reliability tests } \\
\text { in English, French and German: } \\
\text { TPI final version } \\
\text { TEI final version } \\
\text { TNI final version }\end{array}$ & October 1998 / 6 & $\begin{array}{l}\text { UAB, } 68 \text { English students } \\
28 \text { French students } \\
21 \text { German students } \\
\text { Universitat de Vic, } \\
34 \text { English students } \\
\text { Universitat Jaume I, } \\
73 \text { English students }\end{array}$ \\
\hline $\begin{array}{l}\text { Second validity and reliability tests } \\
\text { in English, French and German: } \\
\text { TPI final version } \\
\text { TEI final version } \\
\text { TNI final version }\end{array}$ & May 1999 / 7 & $\begin{array}{c}\text { UAB, } 45 \text { English students } \\
18 \text { French students } \\
8 \text { German students } \\
\text { Universitat de Vic, } \\
27 \text { English students } \\
\text { Universitat Jaume I, } \\
49 \text { English students }\end{array}$ \\
\hline
\end{tabular}

As can be seen in Figure 2, seven pilot tests were carried out. The last two were really validity and reliability tests in which three Spanish universities participated, using samples of students with three different language combinations (English-Spanish, French-Spanish and German-Spanish). All the subjects from the three universities were first-year students, and in all cases the whole class was tested, numbers varying from one measurement to another because the pilot tests were only given to those students who were in class on the day of the test. Both teachers and students consented 
to take part in the study and for the data to be published, as long as the results were anonymous.

The first pilot test took place in October 1996, using the first version of the instruments. The sample was made up of a group of 25 students. The group was chosen randomly from the two groups of translation from English to Spanish in the first year of the Facultat de Traducció i d'Interpretació of the Universitat Autònoma de Barcelona (UAB). The second pilot test was carried out just one year later, in October 1997, with some modifications to the instruments. The sample was chosen from first year students in the same way as on the previous occasion. 27 students took part, all of them different from those who had participated in the 1996 test and were then in the second year.

In February 1998 a third pilot test was conducted with the same group that had participated in the 1997 test. Minor modification had been made to the translation problems instruments as they were asked to translate a different text. 33 students took part, but only 27 were valid, the same ones as had taken the second pilot test. The sample for the fourth pilot test was bigger, as this time texts in three languages were used (German, French and English). The students were all first-year students of the Universitat Autònoma de Barcelona: 13 with the language combination GermanSpanish; 14 French-Spanish; and 28 English-Spanish, divided into two groups. In May 1998, the fifth pilot test was carried out with some changes in the translation problems instrument. Only 19 of the 27 students who had taken the test in October 1997 repeated the test, i.e. $70 \%$ of the total. Finally, tests six and seven were organised in October 1998 and May 1999. They also served as validity and reliability tests for the three measuring instruments, but we will come again to these two last pilot tests later.

\subsubsection{The Fourth and the Fifth Pilot Tests: the Choice of the Source Text}

The aim of the fourth pilot test was to see if the degree of difficulty was the same in the two texts to be used in the first and second measurements (M1 and M2). The procedure used was as follows. The samples were divided randomly into two groups (there were three samples, one for every language combination, as we were going to try two English texts, two German texts and two French texts). Half of each sample were asked first to translate Text A (and answer the TPI questionnaire) and second to translate Text B (and answer the corresponding questionnaire). The other half of each sample were asked to start with Text B and then to do Text A (each with their corresponding TPI). If the results of the TPI for the two groups were the same, or equivalent, this would prove that the degree of difficulty of the two texts was the same.

To choose the texts and identify the translation problems, we were helped by at least two translation experts for each language (English, French and German). All the texts chosen corresponded to the level of the first year in a translation degree programme, that is, they were general texts belonging to text types the students were familiar with (journalistic and commercial texts) and the style was simple and direct. Another characteristic of these texts was that the students were obliged to use their encyclopaedic and cultural knowledge if they were to produce an acceptable translation.

The tests for all three languages were done in April 1998, at the same time and in the same classroom, with several teachers present to prevent students from exchanging 
opinions. The students were allowed to use dictionaries and reference books (grammars, style books, etc.) provided by the teachers. Thus, they all had access to the same books, which they could consult by going to the teachers' desk. The time was limited, each student had 60 minutes to translate each text and to fill in the corresponding TPI questionnaire, so the whole test lasted two hours. All students were able to finish the task in the time provided.

The results of this test were quite different from what was expected, as none of the samples showed total equivalence between Texts A and B. We thus concluded that the texts were not equivalent; however, we also concluded that the problem was not caused by the texts or the selection method, but because as yet there do not seem to be clear criteria to categorise texts for translation according to degrees of difficulty. Certainly, a serious study is needed, but as it was rather outside the scope of this project, we decided to opt for another solution that would ensure that the two texts were of the same degree of difficulty for any student. This was to use the same text for the first and the second measurement, that is, before the students started studying translation at all and after they had received one academic year of translation training.

We are aware that this decision is controversial, because a translator who translates a text for the second time is obviously going to do it in a different way from the first time and will need less time to understand the ST. However, our case is completely different for several reasons. First of all, our sample is made up of students, not professional translators. Secondly, there are eight months between the first measurement and the second, and in that time the text is not to be mentioned or read again. Thirdly, the first measurement takes place on the first day of class in the university, when the students are naturally distracted by many other stimuli. Therefore, the students have practically forgotten the text they had translated when they are asked to translate it again eight months later.

In order to test the validity of this assumption, we decided to do a fifth pilot test in May 1998. We asked the students from the second pilot test, October 1997, to translate the same text they had translated eight months earlier. Afterwards, we interviewed them and asked if they thought the fact that they had translated the same text at the beginning of the year had made any difference. The vast majority of the students replied that they had only been able to remember the text very vaguely. Those who did remember the text could not remember if their translation had been any different, as they could not remember at all how they had translated the text the first time.

\subsubsection{The Sixth and the Seventh Pilot Tests: the Validation of the Three Measuring Instruments}

As we have already said, the sixth and seventh pilot test were aimed at proving that the measuring instruments created, which already had the final format, were reliable and valid. Two reliability tests were carried out: one to determine the sensitivity to change of the three instruments and another to know the degree of generalizability of each of them. Two validity tests were carried out as well: a crossed validation and a content validation.

First of all, we wanted to make sure that the instruments were sensitive to change, since they are to be applied twice, once before the subjects start their training in translation and a second time after the first year of tuition, and so they should be 
able to reflect the changes that have occurred in the level of translation competence of the subjects. Thus, the three instruments were distributed on the first day of class to all first-year students of the three universities already mentioned (see section 3.3. Pilot Studies) and then, again, after eight months of tuition, on the last day of class. Comparing the results of the students at the end of the first year with their own results at the beginning of the year (through a comparison of the means and the standard deviations obtained individually and collectively in every one of the three instruments), we obtained results showing that the instruments were clearly sensitive to change, so much so that in one of the universities, where the students are taught Translation Theory as a subject in the first year, the results of the students at the end of the year in the TNI were more than two points over the students of the other two universities, who are not taught Translation Theory at all during the first year of their degree course.

On the other hand, we also used the Pearson correlation index to see weather the results of the three instruments correlated. By correlating all the results obtained in both measurements (October 1998 and May 1999), we discovered that the results of the TPI and the TEI already correlate in the first measurement and this correlation seems to increase with translation training, whilst the results of the TNI do not correlate with any of the other two instruments.

Secondly, we selected those elements that seemed, a priori, possible extraneous variables for the results of the three instruments and could thus be an obstacle to generalizing the results obtained with the instruments: the assessor, the centre where the subjects study (not because of the Faculty itself, but due to the different academic curricula of every translation faculty) and the language combination of every student.

To test the degree to which these three elements influenced the results of every instrument, we devised a test design which can be seen in Figure 3 and included three different universities, the three language combinations that can be studied in the Spanish translation faculties during the first year of the degree course (English, French and German into Spanish) and two different assessors for every university and for every language combination, so that every instrument of every student (there was a total of 5 groups of students) was assessed twice, one time by every assessor, and then their marks compared to determine the variability obtained.

FIGURE 3

Design to test the degree of generalizability of the results of the three instruments.

(Orozco 2000: 202)

\begin{tabular}{|c|c|c|c|c|c|c|c|c|c|}
\hline \multirow{2}{*}{\multicolumn{2}{|c|}{$\begin{array}{c}\text { University } 1 \\
\text { English }\end{array}$}} & \multirow{2}{*}{\multicolumn{2}{|c|}{$\begin{array}{c}\text { University } 2 \\
\text { English }\end{array}$}} & \multicolumn{6}{|c|}{ University 3} \\
\hline & & & & \multicolumn{2}{|c|}{ English } & \multicolumn{2}{|c|}{ French } & \multicolumn{2}{|c|}{ German } \\
\hline Asse. 1 & Asse. 2 & Asse. 3 & Asse. 4 & Asse. 5 & Asse. 6 & Asse. 7 & Asse. 8 & Asse. 9 & Asse. 10 \\
\hline \multicolumn{2}{|c|}{$\begin{array}{c}\text { Group } \\
\text { A }\end{array}$} & \multicolumn{2}{|c|}{$\begin{array}{c}\text { Group } \\
\text { B }\end{array}$} & \multicolumn{2}{|c|}{$\begin{array}{c}\text { Group } \\
\text { C }\end{array}$} & \multicolumn{2}{|c|}{$\begin{array}{c}\text { Group } \\
\text { D }\end{array}$} & \multicolumn{2}{|c|}{$\begin{array}{c}\text { Group } \\
\text { E }\end{array}$} \\
\hline
\end{tabular}

Universities 1 and 2 only offer one language combination in the first year, that is why the data obtained to determine the difference between language combinations could only be obtained in university 3 and thus the samples of French and German into Spanish are not as wide as English into Spanish. 
The results of every student in every instrument were analysed through a variance analysis, using the intraclass correlations index, for every one of the three elements (university, language combination and assessor).

The data obtained showed that the degree of generalizability of the results of every instrument is different: the results of the TPI do not depend at all on any of the three elements (assessor, university or language combination), whilst the results of the TNI do not depend on the assessor or on the language combination, but they do depend on the university as far as the academic curriculum is concerned (if Translation Theory is taught in the first year, the results are clearly better in all subjects, as seems obvious). Finally, the results of the TEI do not depend on the assessor or on the university, but the data obtained according to the language combination shows a significant difference, which we would challenge: we actually believe that there is an extraneous variable that has not been taken in the study, namely the teaching methodology used, and that this is what has caused the variability between language combinations (since the translation classes were obviously taught by different teachers with different methodologies). The results obtained in a crossed validation, carried out in one of the universities as a validity test, using a double sample and comparing the results of two groups of students, support this idea, since two groups of students of the same university, with the same language combination and the same assessors (whose degree of agreement is more than 95\%) show comparable results at the first measurement (before receiving any translation training) and a clear difference in the results obtained at the second measurement in both the TPI and the TEI, that can be only attributed to the differences in the methodology used in class.

The last test carried out was a content validation of the three instruments, which was made through a questionnaire distributed to ten experts. The ten experts were at the same time professional translators and university teachers of translation. This questionnaire asked them to assess to what extent each of the questions or tasks that make up the instruments measures what is actually intended to be measured through them and finally they were to assess globally the three instruments built. There were three possible answers to each of these questions: (a) 'it does not measure at all what it aims to measure', (b) 'it measures a little of what it aims to measure' and (c) 'it measures completely what it aims to measure.' The results of this test showed that $80 \%$ of the experts considered that the instruments measure globally what they aim to measure, and the other $20 \%$ consider that they measure 'a part' of what is intended to be measured. Therefore, without going into details of the results obtained in every question, we can affirm that the contents of the instruments are valid, although, of course, some points or the formulation of some questions could be improved.

\section{PROPOSAL OF A RESEARCH PROJECT TO STUDY THE ACQUISITION OF TRANSLATION COMPETENCE}

Building measuring instruments would be useless unless an application is provided, and in fact, while building the three instruments presented in this article we already had in mind a possible application: a research project to study the acquisition of translation competence in trainee translators. The project has been fully designed according to the requirements of the scientific methodology of research, and we hope that the study will indeed take place in the near future. 
Figure 4 shows the elements of the project which, in fact, is proposed as a "model" that can be adapted to different research interests. This is why some of the elements are marked with an asterisk, indicating that these particular elements may be varied according to the researcher's interests without modifying the results of the experiment, as will be explained further on.

The main aim of this study is to measure translation competence acquisition in students of translation during the first stage of their training. It is important to bear in mind that we have restricted ourselves to direct translation, that is, the measuring instruments built have been designed to evaluate written translation into the mother tongue. They would have to be modified to measure inverse translation competence.

\section{FIGURE 4}

\section{Main elements of the study proposed}

1. Construct: Translation competence acquisition at its first stage.

2. Independent variables $\left({ }^{*}\right)$ :

(a) Period of exposure to translation training.

(b) Exposure to a specific translation training methodology called "A."

3. Dependent variables:

(a) Students' performance when faced with translation problems.

(b) Students' performance with regard to translation errors.

(c) Translation notions.

4. Sample $\left.{ }^{\star}\right)$ : First year university students divided randomly into two groups: the experimental group and the control group.

5. Measuring instruments:

(a) To measure performance when faced with translation problems.

(b) To measure performance with regard to translation errors.

(c) To measure translation notions.

6. Hypothesis $\left({ }^{*}\right)$ :

(a) Subjects will detect and solve more problems as they progress with their translation training.

(b) Subjects will make fewer errors as they progress with their translation training.

(c) Subjects will acquire more translation notions as they progress with their translation training.

(d) Subjects will detect and solve more problems if they follow the training methodology "A."

(e) Subjects will make fewer errors if they follow the training methodology "A."

(f) Subjects will acquire more translation notions if they follow the training methodology "A."

\subsection{Variables of the study and hypotheses}

In our model, there are two independent variables (those that the researcher manipulates) which can be manipulated either separately, or simultaneously. They are (a) the period of exposure to translation training and (b) the translation training methodology. 


\section{Exposure Time}

The technique used for the period of exposure to translation training is that of testretest. This means that the measuring instruments are applied twice. The first time before the research has started, when the subjects who are beginning to study translation have had no previous contact with translation or translation theories, i.e., the first measurement coincides with the beginning of training, when the subjects begin their degree in translation. After this first measurement, intervention takes place, i.e., the students attend translation classes for 8 months, and at the end of this period the measuring instruments are applied again. They have to be very sensitive to reflect the changes that have taken place over the period of exposure to translation training.

This variable could be modified according to the aims of the research project. Instead of two measurements at 0 and 8 months of training, the researcher could decide to observe the changes that have taken place throughout the whole first cycle of the degree, by taking measurements at the beginning ( 0 months) and at the end of the first cycle, which coincides with the end of the second year at university ( 24 months after the first measurement). In this case it would not be necessary to alter the first three hypotheses, a), b) and c), that are related to this first independent variable, because what is expected to happen is exactly the same, although the length of time has been increased. The only problem in lengthening the period of observation and exposure to training is that it is important to control all the possible random variables during this time so that the results of the measurements are due to the independent variables and not to other uncontrolled random variables. One way to solve this problem in a longer study is to use a control group. The subjects in this group would receive no training in translation, but they would be affected by the random variables in the same way as the experimental group. Thus, it would be possible to distinguish between our independent variable and other possible random variables

The difference between the first independent variable (time) and the second is that the former tries to measure the effect of exposure to translation training, regardless of the teaching method used, while the latter tries to measure differences in results in relation to teaching methodologies.

We are aware that the results of the first measurement will never be 0 , even though the subjects have not yet any experience of translation. They may be "novice" subjects in translation, but they will certainly have prior knowledge, as any person with linguistic competence in two languages will have a certain skill in mediating between these two languages. Therefore, they will be able to produce translations of some kind, regardless of their quality, as Lörscher observed (1991: 151).

In our model of translation competence acquisition, this initial moment in the learning process corresponds to " $a$ state in which the subcompetencies of translation competence either do not exist, or, if they do exist, do not function in an interrelated way" (PACTE, 2000). Therefore, the development between the two measurements will be analysed from each subject's starting point, and this will be considered as point " 0 ." On the other hand, if the researcher wishes to evaluate the behaviour of the whole group, then the real points obtained in the first measurement should be considered.

\section{Teaching method}

The second independent variable, the teaching method, can be manipulated by the researcher and applied actively to the experimental group and not applied at all to 
the control group, thus ensuring that the differences observed are due to the different teaching methods used.

The control group is to be taught traditionally, while the experimental group follows a "learning by tasks" methodology. The objective is to test hypotheses d) e) and $\mathrm{f}$ ), in which we have defined "training methodology A" as "teaching based on learning by tasks." Thus, the general hypothesis that includes d) e) and f) becomes "the subjects will acquire translation competence more rapidly if the teaching they receive is based on "learning by tasks." Descriptions of this methodology can be found in Hurtado Albir 1995, 1996 and 1999a.

However, other researchers can manipulate this point too, choosing two different teaching methodologies and substituting "training methodology A" for whatever method they consider appropriate, or even to test the effect of different translation exercises on the same students, substituting "training methodology A" for "translation exercise A."

As for the three dependent variables of the study, they have already been described, as they are the operationalization of the construct, and have led to the building of the three measuring instruments presented in Section 3. Therefore, we will just mention them again: translation problems, translation errors and translation notions.

\subsection{The Sample}

The sample should be made up of a group of first-year translation students divided randomly into an experimental and a control group. This random division can be done by a computer when the students register for the course, half of the students in group "A" and half in group "B." However, if this system is not available, the researcher can order the group alphabetically and put even numbers in group " $\mathrm{A}$ " and odd numbers in group "B."

This division will ensure that the two groups are equal, because chance will distribute the random variables equally between the two groups, balancing the results. This system will always work unless the sample is not big enough, in which case the probabilities are very high of one group being better than the other, from the beginning. If this is so, the sample should be enlarged.

In any case, whether or not the two groups are equivalent will be clear after the first measurement, as at the beginning of training the results should be equivalent (i.e. variation under $5 \%$ ).

\section{CONCLUSIONS}

Whatever variations are introduced, the main function of the measuring instruments presented is to measure the students' progress in order to learn more about the way they learn to translate. By using the same instruments several times, the researcher is able to know if translation problems are always related to translation errors, if the students learn first to detect problems and then to solve them, if their use of translation strategies to solve problems progresses with their notions about what translation is. One may also find answers to other related questions.

In fact, these instruments are useful for translation teaching in general. They allow teachers to measure their students' progress. Any teacher can analyse the effects 
of any teaching method and then compare different methods over a period of years to discover the advantages and disadvantages of each method. The instruments can be modified to carry out a restricted study, for example, the effect of carrying out a specific task over a period of time, so as to discover what kind of knowledge has increased after completing the task.

The main advantage of using these instruments is that teachers can investigate the acquisition of translation competence on their own, without having to design new instruments, or collaborate with colleagues in other centres. Of course, the instruments' utility will only be confirmed when teachers decide to use them and we can start to compare results. However, we have taken a first step in the measurement of translation competence that may give us valuable information about the acquisition process.

\section{NOTES}

1. See the studies on communicative competence of Hymes 1971, Canale 1983, Widdowson 1989, Spolsky 1989, Bachman 1990, etc.

2. The research presented in this article is part of M. Orozco's doctoral thesis (Orozco, 2000), directed by M. C. Viladrich and A. Hurtado Albir. The theoretical framework of this thesis is based on the holistic, dynamic model of translation competence and its acquisition as evolved by the PACTE group. The group is now investigating the acquisition of translation competence under the direction of A. Hurtado Albir. Members of the PACTE group are A. Beeby, L. Berenguer, D. Ensinger, O. Fox, N. Martínez Melis, J. Matthews, W. Neunzig, M. Orozco and M. Presas (from the Universitat Autònoma de Barcelona, Spain).

3. For more detailed information about PACTE's holistic model of translation competence see PACTE, 2000 and Hurtado Albir, 1999b.

4. See Hurtado Albir 1995 and 1999a for a classification of errors.

\section{REFERENCES}

Alves, F. (1996): “Veio-me um 'click' na cabeça: The Theoretical Foundations and the Design of a Psycholinguistically Oriented, Empirical Investigation on German-Portuguese Translation Processes," Meta 41-1. pp. 33-44.

AtKins, B.T.S. and K. Varantola (1997): “Monitoring Dictionary Use," International Journal of Lexicography, Oxford University Press. vol. 10, 1. pp. 1-145.

Bachman, L.F. (1990): Fundamental Considerations in language Testing, Oxford University Press. Beeby, A. (1996): Teaching Translation from Spanish to English. Ottawa: University of Ottawa Press. BeLL, R.T. (1991): Translation and Translating, London: Longman.

Bell, R.T. (1998): "Psycholinguistic/Cognitive approaches," in M. BAKer (ed.). Encyclopedia of Translation Studies. London: Routledge. pp. 185-190.

CAmpbell, S. (1998): Translation into the Second Language, London: Longman.

CANale, M. (1983): "From communicative competence to communicative language pedagogy," in J.C. Richards \& R.W. Sснмidt (eds.) Language and Communication, London: Longman.

Chesterman, A. (1997): Memes of Translation. Amsterdam/Philadelphia: John Benjamins.

Dancette, J. (1994): "Comprehension in the Translation Process: an analysis of Think-Aloud Protocols," in C. Dollerup and A. LindegaArd (eds.), Teaching Translation and Interpreting 2. Amsterdam/Philadelphia: John Benjamins.

Dancette, J. (1995): Parcours de Traduction: Étude expérimentale du processus de compréhension. Presses Universitaires de Lille.

Dancette, J. (1997): "Mapping Meaning and Comprehension in Translation: Theoretical and Experimental Issues," in J. Danks, G. Shreve, S. Fountain and M. Mcbeath (eds.) Cognitive Processes in Translation and Interpreting. Applied Psychology, vol. 3. Thousand Oaks: Sage Publications. pp. 77-103. 
Dancette, J. et N. Ménard (1996): “Modèles empiriques et expérimentaux en traductologie: questions d'épistémologie”, Meta, 41-1. pp. 139-156.

Dechert, H.W. and U. SANDrock (1986): "Thinking-aloud protocols: the decomposition of language processing," in Соок (ed.) Experimental Approaches to Second Language Learning. Oxford, Oxford University. pp.111-126.

Dollerup, C. (1982): "An Analysis of Some Mechanisms and Strategies in the Translation Process based on a Study of Translations between Danish and English," The Incorporated Linguist, 21-4. pp. 162-169.

Dreyfus, H.L. and S.E. Dreyfus (1986): Mind Over Machine, Oxford, Blackwell.

ElLis, R. (1997): Second Language Acquisition, Oxford, Oxford University Press.

Englund, B. (1993): "Semantic change in Translation - a cognitive perspective," in I. Gambier \& J. Tommola (eds.) SSOTT IV Translation and Knowledge. Finland, University of Turku. pp. 285-296.

Fox, O. (2000): "The Use of Translation Diaries in a Process-Oriented Translation Teaching Methodology," in B. AdAB, \& C. Schaeffner (eds.) Developping Translation Competence. Amsterdam/Philadelphia: John Benjamins.

Fraser, G. (1993): "Public Accounts: Using Verbal Protocols to Investigate Community Translator Training," Applied Linguistics 14-4. pp. 325-343.

Fraser, J. (1994): "Translating Practice into Theory: A Practical Study of Quality in Translator Training," in C. PICKen (ed.) ITI Conference 7 Proceedings, London: Institute of Translation and Interpreting.

Fraser, J. (1996a): “The Translator Investigated. Learning from Translation Process Analysis," in The Translator, 2-1. pp. 65-79.

Fraser, J. (1996b): "Mapping the Process of Translation," in Meta, 41-1. pp. 84-96.

Gerloff, P. (1987): "Identifying the Unit of Analysis in Translation: some uses of Think-Aloud Protocol data," in C. FAerch \& G. KASPER (eds.), Introspection in Second Language Research. Clevedon: Multilingual Matters. pp. 135-158.

Gerloff, P. (1988): From French to English: A look at the Translation Process in Students, Bilinguals, and Professional Translators, Doctoral Thesis, University of Harvard.

González, M., F. Rodríguez, and C. Scott-Tenent (2000): “Translation Strategies: design of a teaching prototype and empirical study of its results," in A BeEBy, D. ENsinger and M. Presas (eds.). Investigating Translation. Amsterdam/Philadelphia: John Benjamins.

Halskov, E. (1998): "Factors influencing unsuccessful translations," in Actas del III Congreso Internacional sobre la Traducción, Facultat de Traducció i d'Interpretació, UAB, marzo de 1996. Barcelona: Universitat Autònoma de Barcelona. pp. 165-172.

Halskov, E. (1999): The Translator and the Legal Text. An empirical study of the effects of linguistic complexity and LSP on the translation of a Spanish text. Unpublished Doctoral Thesis. Copenhagen Business School.

Hansen, G. (1997): "Success in Translation," in Perspectives: Studies in Translatology. 5: 2. pp. 201210.

Hansen, G. (ed.). (1998): "LSP texts and the process of translation," in Copenhagen Working Papers in $L S P, 1$.

Hansen, G. (ed.). (1999): Probing the process in translation: methods and results. Col. Copenhagen Studies in Language, 24. Copenhagen: Samfundslitteratur.

Harris, B. and B. Sherwood (1978): "Translating as an Innate Skill," in D. Gerver \& W. Sinaiko (eds.) Language, Interpretation and Communication. Oxford: Plenum Pres, pp. 155-170.

Hatim, B. and I. Mason (1997): The Translator as Communicator. London: Routledge.

Hewson, L. and J. Martin (1991): Redefining Translation. The Variational Approach. London: Routledge.

Hurtado Albir, A. (1995): "La didáctica de la traducción. Evolución y estado actual," in P. Fernández \& J.M. Bravo (eds.) Perspectivas de la traducción. Valladolid: Universidad de Valladolid. pp. 49-74. 
Hurtado Albir, A. (1996a): "La enseñanza de la traducción directa 'general.' Objetivos de aprendizaje y metodología," in A. Hurtado Albir (ed.) La enseñanza de la traducción, Castellón: Universitat Jaume I, pp. 31-55

Hurtado Albir, A. (1996b): "La cuestión del método traductor. Método, estrategia y técnica de traducción," Sendebar 7.

Hurtado Albir, A. (dir.) (1999a): Enseñar a traducir. Metodología en la formación de traductores e intérpretes, Madrid: Edelsa.

Hurtado Albir, A. (1999b): “La competencia traductora y su adquisición," Perspectives. Studies in Translatology 7: 2. Special Issue on Hispanic Translation Studies, pp. 177-188.

Hymes, D.H. (1971): On Comunicative Competence, Philadelphia: University of Pennsylvania Press.

JäÄSKELÄInEN, R. (1987): What Happens in a Translation Process: Think-aloud Protocols of Translation, University of Joensu, Savonlinna School of Translation Studies. Unpublished Pro gradu Thesis.

JäÄSKelÄInEN, R. (1989): “Translation Assignment in Professional Versus Non-professional Translation: a think-aloud protocol study," in C. SÉGuInot (ed.). The Translation Process. Toronto: H.G. Publications.

JäÄskeläInen, R. (1990): Features of Successful Translation Processes: A Think-Aloud Protocol Study, University of Joensu, Savonlinna School of Translation Studies. Unpublished Pro gradu Thesis.

JäÄSkelÄInen, R. (1993): “Investigating Translation Strategies," in S. Tirkkonen-Condit \& J. LAFFLING (eds.) Recent Trends in Empirical Translation Research, University of Joensuu.

JäÄsKeläInen, R. (1998): “Think-aloud protocols,” in M. BAKer (ed.). Encyclopedia of Translation Studies. London: Routledge. pp. 265-269.

JäÄskeläinen, R. and S. Tirkkonen-Condit (1991): "Automatised Processes in Professional vs. Non-professional Translation: A think-aloud protocol study," in S. TirkKonen-Condit (ed.). Empirical Research in Translation and Intercultural Studies. Tübingen, Gunter Narr.

Jakobsen, A.L. (1998): "Logging time delay in translation," in G. Hansen (ed.) Copenhagen Working Papers in LSP, 1. pp. 73-101.

Jakobsen, A.L. (1999): “Logging target text production with Translog," in G. Hansen (ed.) Probing the Process in Translation: Methods and Results. Col. Copenhagen Studies in Language, 24. Copenhagen: Samfundslitteratur. pp. 9-20.

Jensen, A. (1999): "Time pressure in translation," in G. Hansen (ed.). Probing the process in translation: methods and results. Col. Copenhagen Studies in Language, 24. Copenhagen: Samfundslitteratur. pp. 103-120.

Kiraly, D.C. (1995): Pathways to Translation, The Kent State University Press.

Kiraly, D.C. (1997): "Think-aloud protocols and the construction of a professional translator self-concept," in J. Danks, G. Shreve, S. Fountain, M. Mcbeath (eds.) Cognitive Processes in Translation and Interpreting. Applied Psychology, vol. 3. Thousand Oaks: Sage Publications. pp. 137-160.

Königs, F. G. (1987): "Was beim Übersetzen passiert. Theoretische Aspekte, emprisiche Befunde und praktische Konsequenzen," Die neueren Sprachen 86,2, pp. 162-185.

Königs, F. G. and R. Kauffmann (1996): "Processus mentaux étudiés chez des sujets allemands apprenant le français lorsqu'ils son en train de traduire," Meta, 41-1, pp. 7-25.

KRINGS, H. P. (1986): Was in den Köpfen von Übersetzern vorgeht, Tübingen, Gunter Narr.

Krings, H. P. (1987): “The Use of Introspective Data in Translation,” in C. Faerch \& G. Kasper (eds). Introspection in Second-language Research. Clevedon, Multilingual Matters. pp. 159-176.

Krings, H. P. (1988): “Blick in die 'Black Box' — Eine Fallstudie zum Übersetzungsprozeß bei Berufsübersetzen," in R. Arntz (ed.). Textlinguistik und Fachsprache. Hildesheim [etc.], Olms. pp. 393-412.

Kussmaul, P. (1991): "Creativity in the Translation Process: Empirical Approaches," in K.M. van Leuven \& T. NaAijkens (eds.) Translation Studies: The State of the Art, Amsterdam: Rodopi. Kussmaul, P. (1995): Training the Translator, Amsterdam/Philadelphia: John Benjamins. 
Kussmaul, P. (1997): "Comprehension Processes and Translation: A Think-aloud Protocol Study," in M. Snell-Hornby, Z. Jetmarova, K. Kainde (eds.). Translation as Intercultural Communication. Amsterdam/Philadelphia: John Benjamins. pp. 239-248.

Laukkanen, J. (1993): Routine vs. Non-routine Processes in Translation: A think-aloud protocol study. Finland: University of Joensuu, Savonlinna School of Translation Studies. Unpublished thesis.

Lesgold, A. and R. Glaser (1989): Foundations for a Psychology for Education, Hillsdale: Lawrence Erlbaum Association.

Livbjerg, I. and I.M. Mees (1998): "LSP texts and the process of translation," in G. Hansen (ed.). Copenhagen Working Papers in LSP, 1.

Livbjerg, I. and I.M. Mees (1999): "A study of the use of dictionaries in Danish-English translation" in G. Hansen (ed.). Probing the Process in Translation: Methods and Results. Col. Copenhagen Studies in Language, 24. Copenhagen: Samfundslitteratur. pp. 135-150.

Lorenzo, M. P. (1998): "LSP texts and the process of translation," in G. Hansen (ed.). Copenhagen Working Papers in LSP, 1.

Lorenzo, M. P. (1999a): "Apuntes para una discusión sobre métodos de estudio del proceso de traducción," in G. Hansen (ed.). Probing the Process in Translation: Methods and Results. Col. Copenhagen Studies in Language, 24. Copenhagen: Samfundslitteratur. pp. 21-42.

Lorenzo, M. P. (1999b): "La seguridad del traductor profesional en la traducción a una lengua extranjera," in G. Hansen (ed.). Probing the Process in Translation: Methods and Results. Col. Copenhagen Studies in Language, 24. Copenhagen: Samfundslitteratur. pp. 121-134.

Lörscher, W. (1991): Translation Performance, Translation Process, and Translation Strategies. Tübingen: Narr.

Lörscher, W. (1992): “Investigating the Translation Process," Meta, 37-3.

Lörscher, W. (1993): “Translation Process Analysis,” in Y. Gambier and J. Tommola (eds.) Translation and Knowledge, University of Turku.

Lörscher, W. (1996): “A Psycholinguistic Analysis of Translation Processes," Meta, 41-1. pp. 2632.

Lowe, P. (1987): "Revising the ACTFL/ETS Scales for a New Purpose: Rating Skill in Translating," in M.G. Rose (ed.) Translation Excellence: Assessment, Achievement, Maintenance. American Translators Association Series, vol. 1. New York: SUNY Binghamton Press. pp. 53-61.

Mondahl, M. and A. Jensen (1992): "Information Processing in a Translation Task," Multilingua, 11-2.

Mondhal, M. and A. Jensen (1996): . "Lexical Search Strategies in Translation," Meta, 41-1. pp. 97113.

Neubert, A. (2000): “Competence in language, in languages and in translation," in B. AdAB and C. Schaeffner (eds.). Developping Translation Competence. Amsterdam/Philadelphia: John Benjamins.

Neunzig, W. (1997a): "Der Computer als Hilfsmittel beim Erwerben kognitiver Übersetzungsstrategieen," in E. Fleischmann, W. Kutz and P.A. Sснмitт (eds). Translationsdidaktik. Grundfragen der Übersetzungswissenschaft. Tübingen: Narr. pp. 377-384.

NeunzIG, W. (1997b): "Die Effizienz computergestützter Übungsformen: eine Untersuchung im Rahmen des Übersetzungsunterrichts"

Neunzig, W. (1998): "El ordenador como profesor virtual en la formación de traductores. Simulación de una clase de traducción," in Actas del III Congreso Internacional sobre la Traducción. Barcelona: Universitat Autònoma de Barcelona. pp. 565-579.

Nord, C. (1991): Text Analysis in Translation. Amsterdam: Rodopi.

Nord, C. (1996): "El error en la traducción: categorías y evaluación," in A. Hurtado (ed.) La enseñanza de la traducción, col. Estudis sobre la traducció 3 Castelló: Universitat Jaume I. pp. 91-107.

Nord, C. H. (1992): “Text analysis in translator training," in C. Dollerup \& A. Loddegaard (eds.) Teaching Translation and Interpreting. Amsterdam-Philadelphia: John Benjamins, pp. 39-48. 
Orozco, M. (2000): Instrumentos de medida de la adquisición de la competencia traductora: construcción y validación. Unpublished Doctoral Thesis. Departament de Traducció i d'Interpretació, Universitat Autònoma de Barcelona.

Oxford, R. (1990): Language learning strategies, Boston: Heinle \& Heinle

PaCte (1998): "La competencia traductora y su aprendizaje. Objetivos, hipótesis y metodología de un proyecto de investigación," Poster presented at the IV Congrés Internacional sobre Traducció, Universitat Autònoma de Barcelona.

Pacte (2000): "Acquiring Translation Competence: Hypotheses and Methodological Problems of a Research Project," in A. Beeby, D. Ensinger, M. Presas (eds.). Investigating Translation. Amsterdam/Philadelphia: John Benjamins.

Presas, M. (1996): Problemes de traducció i competència traductora. Bases per a una pedagogia de la traducció, Unpublished Doctoral Thesis, Universitat Autònoma de Barcelona.

Pym, A. (1992): "Translation error analysis and the interface with language teaching," in C. DolLeruP and A. LoddegaArd (eds.) Teaching Translation and Interpreting, Amsterdam/Philadelphia: John Benjamins. pp. 279-288.

Рум, А. (1993): Epistemological problems in translation and its teaching. Teruel: Caminade.

Riedemann, K.(1996): “Cognition and Translation Didactics," in Meta, 41-1. pp. 114-117.

Risku, H. (1998): Translatorische Kompetenz. Kognitive Grundlagen des Übersetzens als Expertentätigkeit, Tübingen, Stauffenburg.

RoIss, S. (1998): Didaktische Überlegungun zur Verbesserung der Methodik in der Hin-Ubersetzung Spanisch-Deutsch. Unpublished Doctoral Thesis. Facultad de Traducción y Documentación de la Universidad de Salamanca.

SChäffner, C. (1993): "Meaning and Knowledge in Translation," in Y. Gambier and J. Tommola (eds.) Translation and Knowledge, University of Turku.

SÉguinot, C. (ed). (1989): The Translation Process. Toronto: H.G. Publications.

SÉguinot, C. (1991): “A Study of Student Translation Strategies," in S. Tirkkonen-Condit (ed.). Empirical Research in Translation and Intercultural Studies, Tübingen: Gunter Narr.

Selinker, L. (1972): “Interlanguage," International Review of Applied Linguistics 19 (3).

Shreve, M.G. (1997): “Cognition and the Evolution of Translation Competence," in J.H. Danks et al. (eds.). Cognitive Processes in Translation and Interpreting, Thousand Oaks: Sage.

Shreve, G., C. Schäeffner, J. Danks and J. Griffin (1993): "Is There a Special Kind of 'Reading' for Translation? An Empirical Investigation of Reading in the Translation Process," in Target, vol. 5, 1. pp. 21-41.

Spolsky, B. (1989): “Communicative competence, language proficiency, and beyond," in Applied Linguistics 10-2. pp. 138-156

C.W. Stansfield, M.L. Scott and D.M. Kenyon (1992): "The Measurement of Translation Ability," in The Modern Language Journal, 76-4. pp. 455-467.

Tirkkonen-Condit, S. (1989): "Professional Versus Non-professional Translation: A Thinkaloud Protocol Study," in C. SÉguinot (ed.) The Translation Process, Toronto, H.G. Publications.

Tirkkonen-Condit, S. (1990): "Professional vs. Non-Professional Translation: A think-aloud protocol study," in Halliday; Gibbons; Nicholas (eds.). Learning, Keeping and Using Language. Amsterdam/Philadelphia: John Benjamins. pp. 381-394.

TirkKonen-Condit, S. (1992): "The interaction of World Knowledge and Linguistic Knowledge in the Processes of Translation. A Think-Aloud Protocol Study," in B. LewandowskaTомаszczyк (ed.). Translation and Meaning. Maastricht: Faculty of Translation and Interpreting.

Tirkkonen-Condit, S. (1993): "What happens to a uniquely Finnish particle in the processes and products of translation?," in I. GAmbier and J. Tommola (eds.). SSOTT IV Translation and Knowledge. Finland: University of Turku. pp. 273-284.

TirkKonen-Condit, S. and LaukKanen (1996): "Evaluations: a key towards understanding the affective dimension of translational decisions," Meta, 41-1. pp. 45-59. 
Toury, G. (1991): "Experimentation in Translation Studies: Achievements, prospects and some pitfalls," in S. TirkKonen-Condit (ed.). Empirical Research in Translation and Intercultural Studies: Selected papers of the TRANSIF Seminar, Savonlinna, 1988. Tübingen: Narr. pp. 45-66.

Toury, G. (1995): Descriptive Translation Studies and Beyond. Amsterdam/Philadelphia: John Benjamins.

Waddington, C. (1999): Estudio comparativo de diferentes métodos de evaluación de traducción general (inglés-español). Doctoral Thesis. Universidad Pontificia de Comillas, Facultad de Filosofía y Letras. Col. Tesis Doctorales, n 17/1999.

Widdowson, H.G. (1989): "Knowledge of Language and Ability for use," in Applied Linguistics 10-2. WiLss, W. (1982): The Science of Translation. Tübingen: Gunter Narr.

WiLss, W. (1989): “Towards a Multi-facet Concept of Translation Behavior,” Target, 34. pp. 129-149.

\section{APPENDIX 1}

\section{TRANSLATION NOTIONS INSTRUMENT}

\section{QUESTIONNAIRE ABOUT TRANSLATION}

Name and Surnames:

Date of birth:

Please do the following exercises keeping to the order given here. You have two hours to complete the three exercises. Your answers will not be taken into account for the grades that you are given for this course, as the evaluators of this test will not be given your name. Therefore, please give spontaneous, honest answers to all the questions.

It is important that you answer the questions in order and that you do not go back to a question you have already answered. If you have any questions, put your hand up and we will try to help you.

\section{GENERAL NOTIONS ABOUT TRANSLATION QUESTIONNAIRE}

(30 minutes)

You will find three kinds of questions in this questionnaire:

A. Multiple-choice questions. Answer them by drawing a circle round the answer you consider to be the best, for example, a) is the right answer:
a)
b)

c)

B. True (T)/ False (F) questions. Answer them by drawing a circle round "T" if you think the statement is true, or "F" if you think the statement is false. In the following example the answer is true.<smiles>[C-]1C=[C-]C1</smiles>

C. Open questions. Answer them by writing your opinion on the dotted lines below each question.

You can begin as soon as you are ready:

1. What is translation for you? Define it in one sentence. 
2. What should a good translator know? List the most important points.

3. Which instruments can help a translator to translate? List all the ones you know.

4. List all the different kinds of translations a professional translator may be asked to do.

5. If you find an English expression that you do not understand in a text, what do you do first? Order the following options, putting a 1 by the one you would choose first and a 3 by the one you would choose last.

consult a bilingual dictionary

_ try to understand the meaning of the word from the context

_ consult a monolingual English dictionary

6. If, when you are translating, you find an English expression that you understand, but that your translation does not express the meaning clearly or exactly enough, what do you do first to find a good equivalent? Order the following options, putting a 1 by the one you would choose first and a 3 by the one you would choose last.

_ consult a bilingual dictionary

_ try to express the same idea in as many ways as possible in Spanish

_ consult a monolingual Spanish dictionary

7. When you are translating, what do you think is the basic unit you are translating?
a. the word
b. the sentence
c. something else:

8. Underline the elements you think intervene in a translation.
client
original author
socio-cultural environment

of the original text.

date of the original text socio-cultural environment of the translated text

date of the translation. original reader.

final reader.

function of the original text.

function of the translation

9. The main problems encountered when translating are vocabulary problems.

$$
\mathrm{T} \quad \mathrm{F}
$$

10. Your translation of a sales contract for the British company, "WHL Inc.," will be different if you are translating it for a lawyer who wants to use it as proof in a trial, or for a Spanish subsidiary company, attached to "WHL Inc." that needs the translation to sign contracts with other Spanish companies.

$\mathrm{T} \quad \mathrm{F}$

11. All translators should be able to translate as efficiently into the foreign language as into their mother tongue.

T F

12. A good translator should be able to translate all types of texts with the same degree of efficiency. $\mathrm{T}$ 
13. When a translator reads a text before translating it, the process is the same as for any other reader of the text.

$\mathrm{T} \quad \mathrm{F}$

14. A bilingual dictionary is the main instrument used to find an adequate equivalent in the target language. $\mathrm{T}$

F

\section{APPENDIX 2 \\ TRANSLATION PROBLEMS INSTRUMENT}

\section{TRANSLATION OF A TEXT FROM ENGLISH TO SPANISH (1 hour)}

Please translate the following test, taking into account the translation brief. You can use the white sheets of paper as rough paper, but your final translation should be written on page 5 of this folder. You can use all the reference books on the teacher's desk to help you with your translation, but you must write the names of the books you have consulted in the columns below the text (page 4 of this folder). Please write the name and the publishing house (for example "Collins bilingual" or "Real Academia Española monolingual") and the word you have looked up. If you consult the same work twice in a row, you can put ditto marks (") on the line below. If you need more space, you can note down the other works you have consulted on the back of the same page (page 4).

Translation brief: A Spanish company has decided to start a business like "The Writers' Bureau," with offices in Madrid, to teach writing in Spanish. You have been asked to translate the following advertisement (see page 4 of the folder), taken from the front page of The Guardian. Your translation will be published in El País exactly as you have delivered it to the Spanish newspaper.

\section{ORIGINAL TEXT:}

\section{Advertisement \\ Would you like to be a writer? \\ by NICK DAWS}

Freelance writing can be creative, fulfilling and a lot of fun, with excellent money to be made as well. What's more, anyone can become a writer. No special qualifications or experience are required.

The market for writers is huge. In Britain alone there are around 1,000 daily, Sunday and weekly papers, and more than 8,000 magazines.

The Writers Bureau runs a comprehensive correspondence course covering every aspect of fiction and non-fiction writing.

The 140,000-word course is written by professional writers and has been acclaimed by experts

\section{Why not be a writer?}

First-class home study course gets you a flying start. Earn while you learn. Expert tutors, personal guidance, help to sell your writing, and much more! It's ideal for beginners. Details free. No cost. No obligation. Send the coupon.

Name

Address

Telephone Postcode 


\begin{tabular}{|l|l|l|}
\hline WORK CONSULTED & PUBLISHING HOUSE & TERM CONSULTED \\
\hline & & \\
\hline & & \\
\hline & & \\
\hline & & \\
\hline & & \\
\hline
\end{tabular}

\section{APPENDIX 3}

\section{QUESTIONNAIRE ABOUT THE TRANSLATED TEXT (30 minutes)}

Answer the following questions about the text you have just translated. If you do not have enough space below each question, copy the number of the question at the end of the page, or on the back of the page and write the answer there. Use all the space you need. You can consult the original text (page 4 of this folder) and your translation (page 5 of this folder) to answer the questions, but remember, you should answer the questions in the given order without going back to previous questions.

1. What is the function or the purpose of the text you have translated?

2. Can you tell from the formal conventions which genre the text belongs to? (for example, recipe, instructions, letter to the editor, etc.)

3. Did you try to identify the main idea of the text before you began to translate? No

Yes What is the main idea of the text?

4. Are there any secondary ideas in the text?

No

Yes What are the secondary ideas in the text?

5. Did you read the whole text through before you started to translate?

Yes How many times did you read it?

No How far did you read (which line) before you started to translate?

6. Which dictionary did you use most frequently?

7. Did this dictionary answer all your questions?

Yes

No

8. Which other works have you used? List them according to frequency of use from most frequent to least frequent.

1

2

3 
9. If you had not been in the classroom, do you think any other instrument might have been useful for your translation?

No

Yes Which?

10. Which problems did you find when you were translating the text? Choose the five most important problems and answer the following questions about them, describing what sort of problems they were and how you solved them.

Problem I (Specify the fragment that caused the problem.)

Solution: Do you think you have solved the problem?

Yes $\rightarrow \quad$ What did you do to solve it?

No $\quad \rightarrow \quad$ Did you try to solve it?

No

Yes $\rightarrow \quad$ What did you do?

Problem II (Specify the fragment that caused the problem.)

Solution: Do you think you have solved the problem?

Yes $\rightarrow \quad$ What did you do to solve it?

No $\rightarrow \quad$ Did you try to solve it?

No

Yes $\rightarrow$ What did you do?

Problem III (Specify the fragment that caused the problem.)

Solution: Do you think you have solved the problem?

Yes $\rightarrow \quad$ What did you do to solve it?

No $\rightarrow \quad$ Did you try to solve it?

No

Yes $\rightarrow$ What did you do? 
Problem IV (Specify the fragment that caused the problem.)

Solution: Do you think you have solved the problem?

Yes $\rightarrow \quad$ What did you do to solve it?

$\begin{array}{ll}\text { No } \rightarrow \quad & \text { Did you try to solve it? } \\ & \text { No } \\ & \text { Yes } \rightarrow \quad \text { What did you do? }\end{array}$

Problem V (Specify the fragment that caused the problem.)

Solution: Do you think you have solved the problem?

Yes $\rightarrow \quad$ What did you do to solve it?

No $\rightarrow \quad$ Did you try to solve it?

No

Yes $\rightarrow$ What did you do?

11. Do you think the following segments of the text are a translation problem (not just for you, but in general)?

A: "flying" (line 21)
a. Yes
b. No.

B: "Sunday and weekly papers" (line 11)
a. Yes
b. No.

C: "It's ideal for beginners. Details free. No cost. No obligation. Send the coupon." (lines 22-23)

a. Yes

b. No.

D: "Britain" (line 10)

a. Yes

b. No.

12. Did you find the following segments of the text a problem to translate?

A: "flying" (line 21)
a. Yes
b. No.

B: "Sunday and weekly papers" (line 11)
a. Yes
b. No.

C: "It's ideal for beginners. Details free. No cost. No obligation. Send the coupon." (lines 22-23)
a. Yes
b. No. 
402 MeTA, XLVII, 3, 2002

D: "Britain" (line 10)
a. Yes
b. No.

13. Did you read your translation over before giving it in? No

Yes

How many times?

How many changes did you make?

14. Qualify the text you have just translated on the following scale of difficulty. Circle the number you think is most appropriate (" 0 " is very easy and " 10 " is very difficult).

VERY EASY

$\begin{array}{lllllllllll}0 & 1 & 2 & 3 & 4 & 5 & 6 & 7 & 8 & 9 & 10\end{array}$

VERY DIFFICULT

If you think the text is difficult, what do you think makes it difficult? 